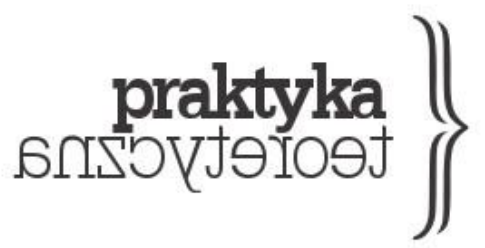

AN ETHICS FOR STATELESS SOCIALISM:

AN INTRODUCTION TO EDWARD ABRAMOWSKI'S

POLITICAL PHILOSOPHY

CEZARY RUDNICKI 
A political philosophy of communism must pose the twofold question of the subject and of the praxis of communist politics. Who is the subject? It is the oppressed, pushed to action by miserable social and economic conditions? Or is it the educated, conscious avant-garde, proponents of humanist ideals leading the way for the masses? And what form should a communist politics take? That of a revolutionary party with the task of taking over the state apparatus? Or that of the spontaneity of the masses, whose accumulated rage pushes them towards direct political action? Such are the questions addressed by the Polish philosopher Edward Abramowski (1868-1918), probably the most influential ideologue of the Polish cooperative movement.

The main goal of Abramowski's political philosophy was to conceptualize the best strategy for the transition to communism, which he often called "stateless socialism." The strategy was to be grounded by establishing various grassroots organizations, such as the educational initiatives, workers' unions, agricultural cooperatives and, above all, consumer cooperatives, and subsequently by merging them into larger groups. Instead of imposing communism from above, the path Abramowski chose was to assemble it from the existing egalitarian and self-governing elements. Secondly, Abramowski strongly emphasized the necessity to develop subjective dispositions that would make individuals capable of leading a communist life. Here the Polish philosopher might have been the most ahead of his time. Although his texts are entangled in the language and concepts characteristic of the positivism of the time and of the philosophy of the will, he managed to articulate a crucial problem for contemporary post-structuralist philosophy: the production of subjectivity. A democratic, communist subject was, for Abramowski, not something given, but something that must first be shaped... or rather provided with conditions for autonomous development. The very work on the (economic, social, biopolitical) conditions for the production of subjectivity was, according to Abramowski, an essential basis for the transition to stateless socialism. But the key moment of that transition was nevertheless the subjective activity of self-transformation. If we call this transformation of the self "ethics", then we can put forward the thesis that the original aim of Abramowski's inquiries was an ethics of stateless socialism.

\section{Outline of a life}

Edward Abramowski was born in the Kiev Governorate on 17 August 1868. After the death of his mother, he moved with his family to Warsaw, which was then located in the Kingdom of Poland (both territories were part of the Russian partition of Poland). In Warsaw, Edward 
and his sister Maria received a solid education. In order to protect them against Russification, the father didn't send them to school, but used only private tutors. Among them were two important figures: Maria Konopnicka (a poet, novelist, children's writer and activist for women's right) and Konrad Prószyński (a writer, editor and founder of the secret Society for National Education [Towarzystwo Oświaty Narodowej]). Another of Abramowski's teachers, Zygmunt Pietkiewicz, introduced him to the environment of the First Proletariat (Krzeczkowski 1924, xv). ${ }^{1}$ In 1885 he moved to Krakow, where he attended gymnasium and audited classes at Jagiellonian University. During his time in Krakow, Abramowski was instrumental in creating socialist circles among students and young craftsmen, but due to a police intervention he was forced to leave for Geneva (Okraska 2012). There he kept in touch with Polish socialist activists and wrote agitation booklets. At the beginning of 1889, Abramowski returned to Warsaw to rebuild socialist structures; among others, the so-called Second Proletariat. During this period, he also undertook studies on capitalism, adopting a Marxist perspective, and published several larger works, including Feodalizm [Feudalism] and Spoleczeństwa Rodowe [Familial Societies], as well as a number of propagandist brochures. For most part, these texts propagated the idea of creating independent workers' organizations - above all Drień roboczy [The Working Day], Rewolucja robotnicza [The Workers' Revolution] and Ustawa ogólnorobotniczej kasy oporu [The Statute of the Workers' Resistance Aid Fund].

In 1892, as a representative of the Workers' Union [Zjednoczenie Robotnicze], he participated in the Paris congress, at which the Polish Socialist Party [Polska Partia Socjalistyczna] was founded. Abramowski had a significant influence on the party's doctrine, strongly emphasizing the necessity to link class struggles with the struggle for Polish independence. He also proposed making use of - for the needs of agitation - religious arguments and motifs, however he failed to convince the majority of delegates at the congress of this idea (Okraska 2012).

The beginning of the 1890 s was not only a period of political commitment for Abramowski. It is also around that time that he first got interested in cooperativism and began to criticize orthodox Marxism. Initially, he stressed the need to emphasize human freedom, moral factors and will as causative forces in historical processes. Later, referring to ethical and subjective factors, he took a clear stance against Marxist naturalism and historical determinism. In the second half of the 1890s Abramowski became interested in psychology. He published two texts in French: Les bases psychologiques de la sociologie. Principe du phénomène social and Le Matérialisme historique et le principe du phénomène social. Finally, starting from the end of the nineteenth century we can speak of his thought taking an ethical turn. This is also when

1 "The First Proletariat" is a colloquial name for the International Social-Revolutionary Party "Proletariat" [Międzynarodowa Socjalno-Rewolucyjna Partia Proletariat] - the first Polish worker party based on Marxist and anarchist ideas. 
Abramowski elaborates the concept of stateless socialism. In 1899 he published one of his most important texts: Etykea a rewolucja [Ethics and Revolution]. In it, he develops a critique of the State apparatus - and in particular of socialist/communist aspirations to take over this apparatus - and introduces the concept of moral revolution, which he opposes to bureaucratic revolution.

Abramowski's activities did not reduce to theoretical practice alone. He also tried to implement his ideas. In Geneva and Zakopane, he, among other things, established "ethician circles" and "communes" with the aim of forging and transmitting new ideas. In 1904, he published Socjalizm a panstwo [Socialism and the State], in which he ultimately took the side of the cooperative movement, at the same time emphasizing its ethical importance. In the same year he joined the Polish People's Federation [Polski Związek Ludowy], a progressive and radical peasant political initiative, for which he co-authored program declarations and wrote articles. In 1905 he published Zmowa powszechna przeciwko rzadowi [General Collusion Against the Government - a manifesto that propagated a widespread boycott of the institutions and structures of the partitioning powers and called for a bottom-up creation of counterinstitutions based on mutual aid, brotherhood and cooperation. Abramowski was also personally engaged in establishing new cooperatives. He joined the Association of Social Mutual Aid Companies [Związek Towarzystw Samopomocy Społecznej], in which he created a separate section - the Cooperativists' Society [Towarzystwo Kooperatystów] - together with the cooperative magazine “Społem!" [“Jointly!’], where he served as the leading publicist.

When the cooperative movement took off, Abramowski focused his activities in other fields. In 1910, he created the Psychological Institute and undertook research in experimental psychology. At about the same time he formulated the concept of the Friendship Unions, the aim of which was to support the cooperative movement and supplement it with mutual aid programs. These two aspects were closely connected. Metafizyka doswiadcralna [Experimental Metaphysics], an extremely important work that he wrote in the last years of his life, devotes an entire chapter to the ethics of friendship, in which the point is to lay bare the psychological and ontological foundations of the dispositions to friendship and cooperation. In 1915, Abramowski was given a chair in Experimental Psychology at the Warsaw University. During this period, he also aided independence initiatives: he became one of the initiators of the 1912 congress, and after the outbreak of the First World War he supported Józef Piłsudski, commander of the Polish Military Organization [Polska Organizacja Wojskowa] and member of the Polish Socialist Party.

Abramowski struggled with tuberculosis all his life. In 1918, his condition got worse. Maria Dabrowska, an acclaimed Polish writer and Abramowski's close friend, wrote in her diary on 17 June 1918: "Tuberculosis and poisoning of the body with cocaine and morphine 
to the highest degree. Further, severe asthma” (Dabrowska 1998, 180). Four days later, on 21 June 1918, Edward Abramowski died. Dabrowska left a literary portrait of the philosopher in her novel Noce $i$ dnie [Nights and Days], where she depicted him as a rationalist and an atheist. Abramowski himself, in many of his texts, used a positivistic and sometimes extremely materialistic language (e.g. he wrote about "the brain" instead of "the mind"). On the other hand, in articles intended for a broader audience, especially those published in the cooperative magazine "Społem!", he repeatedly resorted to religious rhetoric, linking cooperativity and the idea of brotherhood with the Christ's recommendation to love one's neighbor.

\section{Ethics and Revolution}

In one of his most representative texts Abramowski states clearly that, "the alteration of the human world cannot take place through a bureaucratic revolution [...] it can take place only through the moral revolution" (Abramowski 1924c, 319). By the bureaucratic revolution he understands the situation in which a group of revolutionaries manages to take over the state apparatus, whether by conspiracy or through general elections, and to introduce communist institutions and solutions without the conscious participation of the people. Such would amount to an attempt to remove certain legal and economic relations, such as private property or exploitation. Abramowski considers two possible outcomes of this situation. The first is that the moral needs of the people do not change. In this case, the people will still want private property and criminals to be confined to prison. As a consequence, state power will then have to suppress these "natural" needs (characteristic for a given moral type) and defend the newly established institutions. No democratization would occur (because the needs of a morally unrevolutionized people would lead in a different direction), and thus a bureaucratic absolutism would necessarily arise.

In this way, communism would not only be immensely superficial and weak, but, moreover, it would transform itself into statehood, oppressing individual freedom; and in place of the old classes it would create two new ones: citizens and officials, whose mutual antagonism would have to become manifest in all areas of social life (Abramowski 1924a, 272). 
According to Abramowski, even if such a communism were to persist, it would be a social monstrosity and a self-contradiction. It is impossible not to see how prophetic this diagnosis, formulated two decades (!) before the rise of the Soviet Union, was to become.

The second outcome would consist in an automatic moral transformation, which would somehow be the effect of a political transformation. Abramowski refers here to the argument proffered by tenants of bureaucratic revolution, i.e. those who claim that "the moral revolution takes place spontaneously under the influence of economic conditions alone" (Abramowski 1924a, 273). According to them, the party can gain power and carry out social reforms even without the conscious participation of the people: the dissatisfaction and antagonisms created by the previous system and the awareness of movement's leaders are enough as a point of support. Abramowski admits that

the development of economic conditions creates new moral elements $[\ldots]$; for a propagated idea to go deeply enough into the soul of a human being - and to really become its moral transformation, its new need and a new rule of conduct the appropriate life influences are necessary, [influences] that would develop an emotional susceptibility to it [i.e. to that moral transformation - CR] (Abramowski 1924a, 273).

However, Abramowski also notes that dissatisfaction does not necessarily lead to the development of solidarity, mutual aid and friendliness. For example, a (morally) unreformed worker might not feel the interests of the proletariat as his/her own and still might be driven by the individual benefits pertaining to the logic of capitalism. He/she does not desire to abolish private property or to gain more freedom, but rather a higher wage allowing him/her to become a rentier himself/herself. (This is demonstrated by the spontaneous strikes in which what was usually demanded were higher wages, not a shorter working day.) Regarding minor matters, this worker resorts to the help of police and state institutions, thereby recognizing their usefulness and preserving "in the brain some notion of political orthodoxy" (Abramowski 1924a, 274). In case of a social revolution, he/she will seek to exploit it exclusively for himself/herself and to close himself/herself within the private sphere - both in the social and economic sense. And that means - despite the thesis that some socialists defended - that dissatisfaction with life is not necessarily a revolutionary factor. On the other hand, a peasant and a petty bourgeois - those who possess something perceive the revolution as a threat of economic expropriation. This fear develops in them the conservative impulses and an inability to put forward new social solutions. Both cases show that the transformation of the political system and of the socio-economic environment may give rise to conservative attitudes, and hence is not enough for a moral change. 
The conclusion of Abramowski's reflections is clear: it is fallacious to ignore the question of moral transformation or to assume that it will happen spontaneously. The bureaucratic revolution, without the preceding moral revolution, cannot succeed: it will eventually turn into its own caricature - bureaucratic absolutism. This happens because the extant social institutions are sustained by no more than brute force:

They also live in human souls, fixed by the numerous bonds of religion, morality, reasoning, interests and habits, and therefore their destruction is neither easy nor possible through the bureaucratic revolution. Even superficially eradicated, i.e. in the political sphere, they would be revived by virtue of their strength alone as long as they remained intact and preserved in their moral root (Abramowski 1924a, 275).

The dominant proprietary-police system (as Abramowski calls it) is rooted in a proprietary-police ethics. Therefore, an essential and real eradication of this system can take place only through the "introduction of communism to human souls, by awakening communist needs" (Abramowski 1924a, 275), that is, by introducing a communist ethics. The task of the revolution therefore concerns only one thing: the human soul.

It wasn't until the language of post-structuralist philosophy was developed that Abramowski's ideas could find a proper vocabulary and conceptual apparatus: the main problem of Abramowski's political philosophy is the production of subjectivity. On the one hand, the social system, understood as the totality of social, economic and legal conditions as well as the imposed ideology and moral code, influences the processes of subjective formation in accordance with the system's requirements. Feudalism had created a feudal type of subjectivity; capitalism, a capitalist one. On the other hand, a given type of subjectivity seeks to ensure the best living conditions for itself, i.e. it tries to shape the social system according to its needs and habits. When the system and the given form of subjectivity correspond to each other, they strengthen each other. In such a situation all attempts to change the system directly (e.g. through a coup d'état) must end either in failure or in terror. And conversely, when a new subjectivity appears in the framework of a system which does not correspond to it, it will work toward a transformation of that system. That was, according to Abramowski, the case of capitalism: before it became an abstract economic system, capitalism existed as a particular structure of subjectivity (a system of desires and ideas) that slowly began to adapt the existing social system to itself (see Abramowski 1924a, 271).

A new type of subjectivity does not immediately exist in its complete form. Rather, there exist seeds of this new type or - to use Deleuzoguattarian terminology - shifts and deterritorializations of desire which intensify with the development of science, philosophy 
and art, through economic and political struggles and through a new kind of ethical work on the self (through new "technologies of the self", as Foucault would say). Abramowski ascribes a special role to the latter. While all other "intensifications" of new forms of subjectivity define only the environment (the socio-cultural-economic environment), which might favour the transformation of the subject but just as easily stimulate the reactionary attitudes, ethical work is intentional action aimed at metamorphosing subjectivity in a specified direction. When a new subjectivity is ready, when it has adapted all social conditions to itself, the revolutionary overthrow of the existing power and taking over the government becomes only the last, not the first (!), act of emergency of a new social order. An example of such a phenomenon was the transformation of feudal into bourgeois subjectivity - a process that Abramowski tried to describe in his unfinished work Feudalism (Abramowski 1927).

However, what absorbed Abramowski the most - and not only on the theoretical level, but also on the practical one - was to provide the conditions for the development of a new type of subjectivity, the seeds of which had already began to appear. In place of the capitalist subject - a communist or a cooperative one. In order to enable a full development of such subjectivity, it was necessary, according to Abramowski, to stop treating communism only as an economic and legal idea, and to perceive in it also as a matter of individual and collective ethics. To stop seeing communism as a question of the future (a future system) and start treating it as an idea or a principle that can lead human life here and now. To make a revolution that will be a moral revolution, an exercise of the self in the communist way of life. This idea of "everyday communism" can be treated as a prefiguration of today's politics of the common (Hardt and Negri 2009; see also Piskała 2014).

\section{Cooperativism is not enough!}

A special place in Abramowski's conception (or rather strategy) of the transition to communism is occupied by cooperativism. Cooperatives, according to Abramowski, are organizations that allow their members to become economically independent from capitalism and simultaneously conditions for their moral transformation.

Abramowski, who was initially interested in factory struggles (e.g. The Statute of the Workers' Resistance Aid Fund), shifted his attention in the early 1890s to the sphere of consumption. Workers' struggles and organizations would never lose their significance for him. Still in 1912 he would mention workers unions as one of the four most important 
types of cooperative associations (Abramowski 1924b, 220). But it was the consumer cooperatives that, in his theory, would become the key element in the process of freeing the population from the oppression of capitalists. The task of consumer cooperatives is to gather capital in the hands of the working people. Abramowski focuses on the existence of the merchant class, which mediates between producers and consumers at many levels (from wholesalers to shopkeepers). Consumer cooperatives operate on the basis of direct trading and transferring income back to consumers. Dozens or hundreds of people, instead of buying from shopkeepers, organize themselves to buy directly from wholesalers. In this way they purchase goods at a lower price than before. As a result, they can make (private) savings by paying wholesale prices. However, Abramowski states that this is not a truly co-operative solution. The aim is to buy goods at market prices and accumulate the financial gain at the fund of cooperative. This solution, although it does not bring immediate benefits, establishes "a working capital, thanks to which the cooperative can expand its commercial interests and gain a new income" (Abramowski 1924b, 110). (Not to mention the fact the cooperatives were more successful in providing products of higher and tested quality.) Eventually, the accumulated capital would allow the cooperative to buy factories and farmlands and thus take control of production, and do so in a way that is less confrontational than strikes or other forms of factory struggles and without the risk of being left with no means of consumption (as was always the case with a strike, which could be squashed by a coordinated lockout). There is no need to present this process in detail: it is discussed at length by Abramowski in Stateless Socialism, published in this issue of Praktyka Teoretyczna.

However, next to the economic function, cooperatives also have a very important social role to play: they teach people a new way of life. First of all, individual interest coincides here completely with the interest of the community. A member of a cooperative can achieve maximum benefits only if he/she cares about everyone else being able to achieve them. This develops a feeling of solidarity and a feeling of mutual aid not present in a liberally organized society. Secondly, the cooperative is "a school of social self-government and democracy, which cannot be replaced by theories or teachings taken from books" (Abramowski 1924b, 118). A characteristic feature of cooperatives - as Abramowski conceived them - is that each member has the same rights all the others. All decisions are made jointly and the voice of each "shareholder" has an equal importance. Anyone can also be chosen to execute the administrative functions (which are periodic). But what is even more important, the members of cooperative share the same right of initiative. Everyone can present his/her ideas, convince others of them, create resolutions, participate in their improvement and critique. This immediacy of cooperative democracy is the crucial factor for the cooperatives' extraordinary flexibility and the ability to adapt not only to new conditions, but also to new ideas, needs and desires. In this way, the cooperative becomes a structure open to 
the variability and richness of all human types. In all of these points, the cooperative movement differs from the state, which hinders social creativity by its laws and inflexibility, promoting social homogeneity and an environment in which democracy can exist only in the representative form; that is, a form that limits both the ability to influence decisions concerning the community and the ability to come forward with an initiative. What is most important, however, is that the state, unlike cooperatives, does not teach citizens independence, but dependence and obedience. In order to function efficiently, the state requires a servile and slavish people; the cooperative movement, by contrast, involves people who are not only capable of helping each other, but also have strong individualities with the need to arrange their own lives according to their own standards, and who respect the same need in others. The state, however, even a socialist one, is essentially incapable of producing a communist/cooperative subjectivity. Cooperatives, on the contrary, provide a communist subjectivity with all the conditions necessary for its development; they are its "natural environment", its proper "ecological niche." These conditions are so powerful that life itself in the cooperative provokes the individual to change.

And yet, while all of this is necessary, it is not enough. History has shown that despite their decades-long existence, cooperatives have not become a source of social revolution. It seems that there are two reasons for this situation (Piskała 2014, 85). In eastern Europe the potential of cooperatives was crushed in the twentieth century by the allembracing statehood Abramowski so feared. Second, in western Europe, the cooperatives became a part of the free-market economy. Perhaps these cooperatives functioned internally through mutual aid and democratic procedures, but externally they functioned only as selfish, competitively driven economic entities. The solidarity of cooperative members turned out to be only a loyalty limited to its own group. In the worst cases, when cooperatives gathered a substantial capital, they had turned into completely profit-oriented corporations, in which a class of managers slowly detached themselves from "rank-and-file members", eventually becoming private owners of what was once shared. In the west, the "revolutionary situation" created in the cooperatives became only - again in line with Abramowski's fears an instrument for the private interest of "morally un-reformatted" individuals. Neither socialism (the state) nor capitalism will allow the cooperative movement and cooperative subjectivity to develop freely.

I am convinced that Abramowski was aware of both these dangers facing the cooperative movement. And that is why he paid so much attention to the issue of ethical work on the self. And that is why at the end of his life he returned to his old idea of establishing "ethician circles" and gave them a new form - that of Friendship Unions. These organizations were supposed to be a kind of training camp completely devoted to the exercise of a new way of living. Whereas cooperatives are economic organizations and set 
themselves economic goals only, affecting the structure of subjectivity only additionally (Abramowski 1924d, 359-60), organizations are also needed whose aim is exclusively to form a new human being, i.e. to change the very structure of subjectivity. Against Hardt and Negri (2009, 351, 354-355), I want to say that it's extremely important yet not enough to work (or to consume) differently in order to live differently - even if we treat the whole social field as a kind of factory. Everyday cooperativeness can be easily corrupted: it may be only a means to realize capitalistic needs and desires. The communes, ethician circles and Friendship Unions envisioned and established by Abramowski were supposed to counteract the negative tendencies of the cooperatives and allow for the unlearning of egoism and reliance on the state as well as for the common exercise of solidarity, mutual aid and, above all, friendship:

\begin{abstract}
Once we have understood how important it is to make people capable of friendship; once we have seen that not only the good of the individual, but also the power of the nation depends mainly on this; then we must above all ask ourselves how to teach friendship, how friendship can be strengthened, spread and developed among the people (Abramowski 1924d, 358-359).
\end{abstract}

According to Abramowski, this should be accomplished with the help of associations whose areas of activity would extend to all ordinary, everyday matters - the "politics of everyday life." Members of Friendship Unions were to provide each other with free child care, help in case of illness or misfortune, protection against addictions, legal assistance, support in case of conflict with an employer, interest-free loans, mutual education, etc. All such matters, which appeared impossible to solve without state help or considerable cash outlays, turned out to be solvable thanks to simple mutual aid. This everyday help should work to develop in individuals a disposition to friendship, understood as a kind of social bond as well as a force fostering action. (Friendship here plays a similar role to that of love in Commonwealth. See Hardt and Negri 2009, 179-199.) And although friendship develops only as part of the relationship with others (with co-workers, neighbours, people in need) it requires a certain individual effort above and beyond mere coexistence with others.

In his short text The Subject and Power Michel Foucault shows that the struggle for the shape of subjectivity cannot be reduced to struggles for political (ethnic, social, religious) or economic liberation (Foucault 2000, 331). Of course, there can be no question that political and economic conditions affect the structure of subjectivity. However, the proper field of subjectivity's production is ethics, which does not describe the relations of the individual to things (economics), or the relations of the individual to others (politics), but the relation of 
the individual to the self. In order to transform his or her way of life, an individual has to focus attention on the self. During the lectures he gave at the Collège de France, Foucault discussed a vast array of practices of the self, including getting to know oneself, submitting oneself to tests, equipping oneself with some immediately available prescriptions, etc. Examples of such practices can be found scattered across various of Abramowski's texts. For instance, his articles devoted to the question of art discuss the issue of focusing on oneself, "looking inside oneself" and discovering that the foundation of subjectivity is not the individual, but the non-individual, or trans-individual. The contemplation of works of art is presented here as a practice of liberating oneself from selfishness and moral narrowmindedness (Abramowski 1927a). Moreover, the numerous statutes (of communes, ethician circles and Friendship Unions) written by Abramowski can easily be treated as peculiar, communist "monastic rules" that provide prescriptions for the individual. ${ }^{2}$ Abramowski's concept of exercising the self in friendship should be put in the same context. He understood friendship as the most important feature organizing the structure of communist/cooperative subjectivity; as something without which the member of a cooperative is unable to resist the negative influence of the state or free market competition.

\footnotetext{
${ }^{2}$ For a genealogical critique of monastic rules as ethical texts see Agamben 2013, esp. chapter 1, \2, "Rule and Law").
} 


\section{References}

Abramowski, Edward. 1924a. Etyka a rewolucja. In Edward Abramowski. Pisma. Tom 1.

Warszawa: Związek Polskich Stowarzyszeń Spożywców.

Abramowski, Edward. 1924b. Kooperatywa jako sprawa nyzwolenia ludu pracujacego. In Edward

Abramowski. Pisma. Tom 1. Warszawa: Związek Polskich Stowarzyszeń Spożywców.

Abramowski, Edward. 1924c. Ustawa stowarayszenia “Komuna." In Edward Abramowski. Pisma.

Tom 1. Warszawa: Związek Polskich Stowarzyszeń Spożywców.

Abramowski, Edward. 1924d. Zwiqzki Przyjaźni. In Edward Abramowski. Pisma. Tom 1.

Warszawa: Związek Polskich Stowarzyszeń Spożywców.

Abramowski, Edward. 1927a. Co to jest sqtuka? In Edward Abramowski. Pisma. Tom 3.

Warszawa: Zwiazzek Spółdzielni Spożywców Rzeczpospolitej Polskiej.

Abramowski, Edward. 1927b. Feodalizm. In Edward Abramowski. Pisma. Tom 3. Warszawa: Związek Spółdzielni Spożywców Rzeczpospolitej Polskiej.

Agamben, Giorgio. 2013. The Highest Poverty: Monastic Rules and Form-of-life. Trans. A. Kotsko. Stanford, California: Stanford University Press.

Dąbrowska, Maria. 1998. Dzienniki. Tom 1: 1914-1925. Warszawa: "Czytelnik."

Foucault, Michel. 2000. The Subject and Power. In Michel Foucault. Power. Essential Works of Foucault 1954-1984. Vol 3. Ed. J.D. Faubion. Trans. R. Hurley and others. New York: New Press.

Hardt, Michael, and Antonio Negri. 2009. Commonwealth. Cambridge, Mass.: Harvard University Press.

Krzeczkowski, Konstanty. 1924. Edward Abramowski. 1868-1918. In Edward Abramowski. Pisma. Tom 1. Warszawa: Związek Polskich Stowarzyszeń Spożywców.

Okraska, Remigiusz. 2012. Braterstwo ponad wszystko. Edward Abramowski jako wizjoner spółdzielczości. In Edward Abramowski. Braterstwo, solidarność, wspótdziałanie. Pisma spótdrielcze i stowarayszeniowe. Warszawa: Stowarzyszenie "Obywatele Obywatelom."

Piskała, Kamil. 2014. "Praktykowanie utopii. Edward Abramowski i powracające »widmo komunizmu«." Hybris 25: 66-92.

http://magazynhybris.com/images/teksty/25/05.Piskala.pdf. 
Cezary Rudnicki - a nomad and pagan; editor and co-founder of Machina Myśli (http://machinamysli.org/), an Internet portal to popularize philosophy. $\mathrm{He}$ is also a $\mathrm{PhD}$ student at the Department of History of Contemporary Philosophy at the Warsaw University, where he is preparing a dissertation devoted to the ethics of the self. He has published articles on Deleuze and Guattari, Foucault, Benjamin and Mumford. He recently started working at the Department of Social Thought, European Solidarity Centre.

CITATION: Rudnicki, Cezary. 2018. "An Ethics for Stateless Socialism: An Introduction to Edward Abramowski's Political Philosophy." Praktyka Teoretyczna 1(27): 20-33.

DOI: $10.14746 /$ prt.2018.1.1 